\title{
ORGANIZATIONAL AND LEGAL PRINCIPLES OF THE DIGITAL SOCIETY'S BUILDING IN UKRAINE
}

\section{Brus T. M.}

\section{INTRODUCTION}

Modern society is characterized by globalization and informatization. The EU's Digital Economy Initiatives are the Industrial Policy for the Globalization Era 2020; The Digital Agenda for Europe and the Entrepreneurship 2020 Strategy. The key components that make up the «digital» economy and are in the focus of the «Digital Agenda -2020» are the «digital» industry (ICT as a sector of economy), «digital» infrastructure, «digitization» of business, industry.

The Digital Agenda for Europe, developed by the European Commission back in 2010, identified the leading role of the use of information and communication technologies (ICT) to achieve Europe's goals and priorities by 2020. Successful implementation of this Agenda will accelerate innovation, economic growth and improve life citizens and businesses and easier access to government services and personal development.

Outside of the current global trends of digitization (digitization), Ukraine has not remained. Building a new information society, or as it is called, a «digital» society, challenges the public administration and opens new opportunities.

Prime Minister of Ukraine O. Goncharuk said that 2020 will be a crucial year for Ukraine in the field of digitization. The state needs to fully switch to digital mode and comply with the concept of «The State in a smartphone». If the digitalization goals are achieved, Ukraine's GDP growth plan of $40 \%$ will be realistic in five years.

Digitalization is defined as the saturation of the physical world with electronic-digital devices, facilities, systems and the establishment of electronic-communication exchange between them, which in fact allows for the integral interaction of the virtual and the physical, that is, creates 
cyber-physical space. Its main purpose is to achieve the digital transformation of existing and the creation of new industries, as well as the transformation of life spheres into new more efficient and modern ones. Such an increase is only possible if ideas, actions, initiatives and programs related to digitization are integrated, in particular, into national, regional, sectoral strategies and development programs.

Creating digital infrastructures is a major factor in increasing citizens' access to the global information environment and knowledge. Back in 2011, free access to the Internet was recognized by the UN as a fundamental human right - digital law.

According to scientists, if Ukraine develops under the target scenario of digitization in the next 5-10 years and a significant proportion of the digital economy (up to $65 \%$ of GDP) will appear in the structure of the economy, then the nominal GDP of Ukraine will increase to 1 trillion US dollars. To reach this level, Ukraine must ensure the rule of law and remove the institutional (legislative, tax, etc.) barriers that hamper the development of the digital and innovative economy; to promote continuous state stimulation of digitization of economic and business sectors; to initiate transformation projects on the basis of modern models of public-private partnership.

As the practice of developed countries shows, the introduction of digital technologies significantly increases the efficiency of different sectors of the economy and business and their growth in relation to those who do not use digital technologies.

Therefore, the digitalization of society puts before the public administration a number of tasks that are necessary for the fulfillment. Providing public services in electronic form is one of the priority directions of e-government building in Ukraine. This will not only facilitate citizens' access to them, but will also help minimize corruption risks, attract investment in the Ukrainian economy and increase public confidence in the government.

The introduction of e-government will help create a state that is geared to meeting the needs of citizens and will meet the challenges of the digital society. 


\section{Areas of using electronic technologies in public administration}

The use of new electronic technologies in public administration can be pursued in several strategic directions. Attention is drawn to some of them, as defined by the Concept of Development of the Digital Economy and Society of Ukraine for 2018-2020 and the plan of measures for its implementation, which were approved at the beginning of 2018 by the decree of the Cabinet of Ministers of Ukraine:

1. Creating «digital» jobs for civil servants. In a digital economy, jobs are no longer tied to physical jobs. They become «digital», virtual, mobile, that is, do not require a permanent employee in the workplace. The concept of «digital jobs» is spreading extremely fast in the business environment and is favorably received by the overwhelming majority of workers who like flexible working methods, the ability to work from home, on vacation, from anywhere. In the future, those countries that break down barriers between people, jobs and technology and empower their citizens will be successful, allowing them to be effective and creative regardless of location. Digital technologies are a catalyst for new ways of working ${ }^{1}$.

It is clear that not all public servants will be able to work in digital workplaces. This will be determined by the range of tasks and powers of civil servants, which will be more likely to be related to the provision of services to citizens and businesses online. However, even the partial transfer of civil servants' jobs into the digital space will significantly reduce the costs of hardware and organizational support, maintenance of office space, business trips and more. But at the same time, this area is connected with the need to develop digital skills for civil servants, which should become one of the priorities of public service and local selfgovernment personnel policy.

2. Introduce the concept of open data, according to which certain data should be free for use and disseminated by any person, subject to the rules of attribution and (or) share-alike license. Some positive developments in this direction have already been made. In accordance

1 Лопушинський І.П. «Цифрові робочі місця» державних службовців як вагома складова електронного урядування в Україні. Теорія та практика державного управління і місиевого самоврядування. 2018. № 1. URL: http://nbuv.gov.ua/UJRN/Ttpdu_2018_1_29 
with the Law of Ukraine «On Access to Public Information» No. 2939VI of January 13, 2011, and the Law of Ukraine «On Amendments to Certain Laws of Ukraine on Access to Public Information in the Form of Open Data» of December 25, 2015 No. 922- VIII Open Data Work started in Ukraine. The latter one defines the concept of public information in the form of open data - public information in a format that allows its automated processing by electronic means, free and free access to it, and its further use ${ }^{2}$.

In accordance with the Cabinet of Ministers Resolution «On Approval of the Regulation on Datasets to be Disclosed in the Form of Open Data» No. 835 of October 21, 2015 A Single State Open Data Portal was created and Open Data services are operating on the web pages of some central executive bodies ${ }^{3}$.

The most important achievement of the regulation of the open sphere is that the following important aspects are enshrined in legislation: the open data sphere is defined; a regulatory body has been identified; a designated governing body; identified the main datasets; the technical requirements for open data formats and distribution methods are defined.

Recently, the concept of open data is rapidly gaining ground. Increasingly open data are used in the development of socio-economic development programs of the state and regions. Using of open data in a business environment helps create conditions for market competition. Thanks to this concept, citizens are more able to obtain any information about the activities of public authorities and the provision of administrative services.

However, the capabilities of this tool as a tool for assessing and monitoring the work of public authorities and public administration are not yet fully utilized.

3. In the context of the need to solve problems of improving the quality of services, optimizing the number of employees and reducing

\footnotetext{
${ }^{2}$ Про внесення змін до деяких законів України щодо доступу до публічної інформації у формі відкритих даних. Закон України від 25 грудня 2015 р. № 922-VIII. URL: https://zakon.rada.gov.ua/laws/show/319-19 (дата звернення 27.09.2019)

${ }^{3}$ Про затвердження Положення про набори даних, які підлягають оприлюдненню у формі відкритих даних. Постанова Кабінету Міністрів від 21 жовтня 2015 р. № 835. URL: https://zakon.rada.gov.ua/laws/show/835-2015-\%D0\%BF
} 
the costs of special importance are the so-called «digital» platforms, which will allow simplifying and optimizing internal processes in the organization, improving interaction with citizens and reducing financial and resource costs for the tasks. The most useful models of digital platforms that can be used in public administration are Business to Government (B2G), Consumer to Government (C2G), Government to Consumer (G2C), Government to Business (G2B), and Government to Government (G2G).

Model «a government for citizens» (G2C) will allow to decrease the time of delivery of certificates, receipt of forms and other information by citizens, and will minimize a necessity to stand in turns. It, in turn, will give possibility to save the resources of budget and citizens' money.

Model «a government for a business» (G2B) will allow to automatize tax payments, to conduct electronic tender procedures on supplying with products and others like that. Due to the principle of transparency it will allow to save large money.

Model «a government for a government» (G2G) will allow to automatize relations and circulation of documents between departments, to manage work of state machinery, to conduct internal office work and coordinate activity of regional managements and territorial subdivisions, that largely will promote efficiency of public government bodies.

It is the government's task to use these models as quickly as possible in their activities to improve their efficiency.

4. Using of analytics as a continuous and dynamic process of data collection and analysis in all areas will allow to obtain the necessary and structured information for solving operational and situational tasks, developing plans, programs, initiatives and more. The use of analytics at all stages of the activities of public authorities and in the provision of public and administrative services, the constant collection of data and their rapid processing with the help of special information systems will allow prompt and effective management decisions.

5. Using blockchain technology to create a digital state and prevent corruption in public administration.

This technology is based on the creation of a decentralized, secure database that cannot be changed. Today, in state information systems, human data is very unreliably stored in different state centralized 
databases in different registers. Blockchain technology will allow the creation of a user's electronic cabinet, which will store information about the user from different registers, which he will be able to obtain independently without the help of the staff of administrative centers.

This technology was first used for the financial sector in the creation and use of cryptocurrencies. But it is of interest to other areas, such as banking institutions or government agencies that provide access to large databases such as medical records, retirement benefits, and more.

However, all these changes require regulatory and organizational support, which in turn makes it necessary to amend the existing regulatory framework. The magnitude of such changes may vary: from issuing an internal order of the executive authority to create a structural unit whose main function will be to provide electronic services, to amending the legislation governing the provision of such services. As a rule, such changes relate to the re-engineering of the process of providing the service electronically, as this process becomes much simpler and faster and, unlike the paper form, does not have such a large number of restrictions and requirements.

The State Agency for Electronic Governance of Ukraine (hereinafter - the Agency), which was established on October 1, 2014, has been responsible for the implementation of the Government's policy in the field of e-government, informatization, development of the information society, formation and use of national electronic information resources, digitization of state authorities. The Agency had the status of a central executive body, the activity of which is directed by the Cabinet of Ministers.

On September, 2, 2019 Resolution of Cabinet of Ministers accepted "Some questions of optimization of the system of central executive that Agency was regenerate on Ministry of digital transformation of Ukraine bodies", and a head of new Ministry is under an obligation in ten days' term to provide preparation and introducing Cabinet of Ministers of Ukraine of project of position and suggestions in relation to bringing to the acts of legislation of changes that swim out from the accepted 
resolution ${ }^{4}$. Probably, basis of development of Statute about new Ministry will be position about the State agency on questions the electronic management of Ukraine.

In accordance with Statute Agency carried out the activity after such basic directions:

- grant of electronic administrative services with providing of principles of comfort, transparency, availability, that is able to show out co-operation between the state and citizens on a new, higher level;

- realization of public policy is in the field of forming of open data that can characterize efficiency of work of public power. They are used by both government bodies and scientific, research, educational establishments, commercial companies and citizens. On the basis of open data the useful create to business and society services. The process of opening of data not only assists to development of digital economy in Ukraine but also approaches our country to competent included in European community;

- ensuring electronic interaction of state registers, ie interoperability. Unification of state registers into a single system of interaction is an effective way of optimizing the work of state bodies, combating bureaucracy, ensuring remote and prompt access of citizens to quality administrative services. In particular, «Trembita is introduced» - a system of interaction of state electronic information resources, and a National Register of Electronic Information Resources is being formed;

- ensuring the introduction of electronic document flow into the activities of public authorities, which significantly increases the speed of decision-making and, consequently, the speed of response and resolution of social problems;

- creation of a national system of electronic identification of Ukraine, which helps to give access to data or services. Among the tools of electronic identification are the electronic signature, MobileID, BankID, ID card;

4 Деякі питання оптимізації системи центральних органів виконавчої влади . Постанова Міністрів України від 02 вересня 2019 p. № 829 URL: https://www.kmu.gov.ua/ua/npas/deyaki-pitannya-optimizaciyi-sistem-829. 
- promoting the implementation of e-democracy tools that enable citizens to participate in government decision-making and local selfgovernment;

- ordering the formation and responsibility for the implementation of the National Informatization Program to coordinate the planning and implementation of information projects within the system of state authorities 5 .

Another normative document defining the directions of digital development in Ukraine is the Cabinet of Ministers Resolution No. 56 «Some Issues of Digital Development», according to which the implementation of the principles of the state policy of digital development in the realization of citizens' rights and freedoms is ensured by the executive authorities in the process of preparing new normativelegal acts or amendments to regulations and the exercise of power through the use of digital technologies ${ }^{6}$.

The Cabinet of Ministers also introduces a number of amendments to the normative acts aimed at improving the existing regulatory basis for documenting administrative information in the electronic form of executive bodies and local self-government. In particular, changes were made to the Regulations on State Registration of Regulatory Acts of Ministries and Other Executive Bodies, approved by the Decree of the Cabinet of Ministers of Ukraine of December 28, 1992. No. $731^{7}$ and the Regulation of the Cabinet of Ministers of Ukraine, approved by the resolution of the Cabinet of Ministers of Ukraine of July 18, 2007. No. $950^{8}$ on digital expertise. If the draft act deals with the issues of informatization, e-government, formation and use of national electronic information resources, development of information society,

5 Про затвердження Положення про Державне агентство з питань електронного урядування України. Постанова Кабінету Міністрів України від 01.10.2014 № 492. URL: https://zakon.rada.gov.ua/laws/show/492-2014-\%D0\%BF.

${ }_{6}^{6}$ Деякі питання цифрового розвитку. Постанова Кабінету Міністрів від 30 січня 2019 p. №56 URL: https://zakon.rada.gov.ua/laws/show/56-2019-\%D0\%BF.

${ }^{7}$ Про затвердження Положення про державну реєстрацію нормативно-правових актів міністерств та інших органів виконавчої влади. Постанова Кабінету Міністрів України від 28 грудня 1992p. №731. URL: https://zakon.rada.gov.ua/laws/show/731-92-\%D0\%BF.

${ }_{8}^{8}$ Про затвердження Регламенту Кабінету Міністрів України. Постанова Кабінету Міністрів України від 18 липня 2007p. № 950. URL: https://zakon.rada.gov.ua/laws/show/ 950-2007-\%D0\%BF. 
e-democracy, provision of administrative services or digital development, together with a legal act, the State Agency shall submit a conclusion to the state registration authority. e-Governance Issues on Digital Expertise in the Form Specified in Annex 21 to the Cabinet of Ministers of Ukraine Regulation the Cabinet of Ministers of Ukraine'.

Changes were also made to the resolutions of the Cabinet of Ministers of Ukraine of July 18, 2007 No. 950 and of January 17, 2018, No. 55, in terms of translating the work of executive bodies into electronic form, as well as creating a complete process of organizing interaction in the system of executive bodies exclusively in paperless form ${ }^{10}$.

The main result of the changes in the regulatory framework will be the complete translation of the work of the executive bodies into electronic form, as well as the creation of a coherent process of organization of interaction in the system of executive authorities exclusively in paperless form, completion of the complete cycle of preparation of draft acts in electronic form.

\section{Features of providing digital administrative services}

The implementation of the state digital development policy in Ukraine is based on the following principles:

- openness - is to ensure open access to departmental data (information), unless otherwise provided by law;

- transparency - providing open external interfaces to departmental information systems, including application programming interfaces;

- reusability - is to ensure open inter-agency sharing of solutions and their re-use;

- technological neutrality and portability of data - is to provide access to departmental services and data and re-use regardless of technologies or their products;

\footnotetext{
9 Деякі питання цифрового розвитку. Постанова Кабінету Міністрів від 30 січня 2019 p. №56. URL: https://zakon.rada.gov.ua/laws/show/56-2019-\%D0\%BF

${ }^{10}$ Про внесення змін до постанов Кабінету Міністрів України від 18 липня 2007 р. № 950 і від 17 січня 2018 р. № 55. Постанова Кабінету Міністрів України від 17 квітня 2019 p. № 375. URL: https://zakon.rada.gov.ua/laws/show/375-2019-\%D0\%BF.
} 
- citizen-oriented - is to ensure that the needs and expectations of citizens are first and foremost taken into account when deciding on the forms or methods of exercising state functions;

- inclusiveness and accessibility - providing opportunities for all citizens to enjoy the latest advances in information technology access to services;

- security and confidentiality - is to ensure for citizens and economic entities a safe and secure environment in which electronic interaction with the state occurs, including its full compliance with the rules and requirements established by the laws of Ukraine on protection of personal data and information belonging to the state, electronic identification and trust services;

- multilingualism - is to ensure that administrative, information and other services, including cross-border, are provided to citizens and economic entities, using the language of their choice;

- decision-making support - is to ensure the use of the latest information technologies for the development of software products that support decision-making by the executive authorities in the exercise of power;

- administrative simplification - is to accelerate and simplify administrative processes through their digital development;

- retention of information - is to ensure the storage of decisions, information, records and data, reliability and integrity, as well as their availability in accordance with security and confidentiality policies for a certain period of time;

- evaluation of efficiency and effectiveness - is to carry out a comprehensive evaluation and comparison of at least two alternative solutions to ensure the effectiveness and efficiency of the exercise of power $^{11}$.

The law of Ukraine «On administrative services» determined that the administrative services in electronic form are provided via the Unified state portal administrative services, including through the integrated information system of state bodies and bodies of local self-government.

11 Деякі питання цифрового розвитку. Постанова Кабінету Міністрів від 30 січня 2019 p. №56. URL: https://zakon.rada.gov.ua/laws/show/56-2019-\%D0\%BF 
The procedure and requirements for integration of information systems of state bodies and bodies of local self-government of the Unified state portal of administrative services approved by the Central Executive body, providing forming of state policy in the sphere of providing administrative services, together with the Central Executive body, providing forming of state policy in the sphere of e-government development ${ }^{12}$.

Today the greatest time with the introduction of e-services is play a paper form in electronic form in the development of software to provide electronic services. As an alternative solution to this problem, experts suggest amending the legislation with a view to securing the possibility of filing signed by the electronic digital signature of the data.

The portal of the Government of Ukraine in the section Electronic Services contains a list of electronic services in 9 categories, totaling 129. The principle of «life and business situations» applies when forming new e-services, and allows faster and more efficient response to citizens' requests.

A single state portal for administrative services has also been introduced, where citizens and businesses can obtain information on the location, documents required to obtain administrative services, including information that can be obtained electronically.

The entity providing the administrative service, enterprise, institution or organization within its field of management, possessing the documents or information required to provide the administrative service, shall:

1) to provide such documents or information for free within three working days of receiving the request from the subject of the administrative service, unless otherwise provided by law;

2) take measures to develop the system of interdepartmental electronic interaction, to provide free and open access to their information systems and databases, unless otherwise provided by law;

12 Про адміністративні послуги. Закон України від 11.06.2017 № 5203. URL: https://zakon.rada.gov.ua/laws/show/5203-17. 
3) ensure, in accordance with the law, the storage and protection of information obtained as a result of the provision of administrative services;

4) provide free remote access to their own information systems and electronic databases (registers) containing information necessary for the provision of administrative services, administrators of administrative service centers and entities providing such administrative services, including through the system of electronic interaction of public electronic information resources;

5) take measures to introduce the provision of administrative services in electronic form ${ }^{13}$.

The use of digital signatures empowers the extension of electronic administrative services. Nowadays, the use of electronic digital signature is determined by the Laws of Ukraine «On Electronic Document and Electronic Document Management» ${ }^{14}$ and «On Electronic Trust Services» ${ }^{15}$.

However, the introduction of electronic document circulation marked the adoption of the 1999 European Union Directive on Electronic Signatures. This Directive has enabled Member States to develop their own electronic records policies. It had both positive and negative consequences. On the one hand, it has legitimized electronic document flow and data exchange, even if the latter is unencrypted by cryptographic tools. On the other hand, such independence led to the creation of different and incompatible systems of verification and identification in different countries, which did not contribute to the creation of a single market.

In the course of harmonization of the Ukrainian legislation with the European one in Ukraine, in 2003 the Law on Electronic Digital Signature was adopted, which for the first time introduced the concept of electronic signature and electronic digital signature into legal circulation.

13 Про адміністративні послуги. Закон України від 11.06.2017 № 5203. URL: https://zakon.rada.gov.ua/laws/show/5203-17.

${ }^{14}$ Про електронні документи та електронний документообіг. Закон України від 22 травня 2003 р. № 851-IV. Відомості Верховної Ради Украӥни (ВВР), 2003, № 36, ст. 275.

${ }^{15}$ Про електронні довірчі послуги. Закон України від 5 жовтня 2017 р. № 2155-VIII. Відомості Верховної Ради (ВВР), 2017, № 45, ст.400. 
These concepts are gaining ground in the business environment and the administrative field.

In 2016, the European Directive was repealed and replaced by the EU Regulation 2014 on electronic identification, verification and trust services.

Ukraine is responding accordingly: the Law on Electronic Digital Signature expired on December 7, 2018, but the Law on Electronic Confidential Services was adopted.

According to the latter, the digital signature is electronic data that is added by the subscriber to other electronic data or logically connected with them and used them as a signature, that is, give the possibility to identify a person that signed a particular document. Legal status equivalent to a handwritten signature or seal ${ }^{16}$.

With the services a digital signature to sign electronic documents, to use electronic services, registered in the state portals of the kind. The documents, signed with digital signature have the same legal force as usual.

From the benefits of using electronic digital signature I would like to highlight the following:

- reducing the time for transfer of electronic records unlike paper;

- ease of use of the electronic signature. The key is to have computer and access to the Internet;

- cryptographic transformation of data allows you to ensure the security and confidentiality;

- ease of communication with the public authorities in the preparation of reporting documentation, creating and sharing data etc.;

- increasing the number and accelerating the implementation of business communications.

The law of Ukraine «On electronic trust services» also determines that the electronic signature or seal cannot be recognized as invalid and denied the opportunity to be considered as evidence in court cases solely on the grounds that they are electronic or do not meet the requirements for qualified electronic signature or seal. From this point of view, the

\footnotetext{
${ }^{16}$ Про електронні довірчі послуги. Закон України від 5 жовтня 2017 р. № 2155-VIII. Відомості Верховної Ради (ВВР), 2017, № 45, ст.400.
} 
legal status of the simple electronic signature remains the same - the lack of qualification does not make the document so signed is automatically null and void, but the degree of credibility may be low. Qualified electronic signature, on the contrary, has the presumption of authenticity. Advanced signature takes a middle position: its authenticity cannot be presumed, however, the Law sets the schema with such a signature, the average level of reliability ${ }^{17}$.

It should be noted that the Law imposes special requirements on qualified providers of electronic trust services, namely: such a provider (which may be a natural or legal person) must, in addition to other organizational and technical measures, certify its complete information security system. It should be noted that accredited key certification centers established under the Law on Electronic Trust Services receive this status automatically and must be entered into the Trust List automatically by the Central Certifying Authority within one year after the Law enters into force.

Digital signature is becoming increasingly important, especially after choosing a course on the concept of «The State in a smartphone», an electronic project that aims to enable citizens to receive all necessary information and government services through gadgets. But this will only be possible if citizens receive a digital signature. In our opinion, such a policy is necessary and also envisages educational activities aimed at overcoming the resistance of the population to everything new and unknown.

Digitization of all areas of public activity will promote the transformation of the Minister of Digital Transformation to the level of Deputy Prime Minister, as well as the introduction into the functions of one of the Deputy Ministers in the Ministry, as well as the Deputy Head in each regional state administration responsible for the implementation of digital transformation.

Thus, at the present stage of development of the Ukrainian economy, political will has finally emerged to implement the changes in the field of digitization. Since such changes are not possible without changes in the

\footnotetext{
${ }^{17}$ Про електронні довірчі послуги. Закон України від 5 жовтня 2017 р. № 2155-VIII. Відомості Верховної Ради (ВВР), 2017, № 45, ст.400.
} 
public administration system, and inevitably entail the development of electronic services and changes in the system of their provision, certain changes have already been initiated in the organizational structure of the authorities and the regulatory provision for digital transformations in the state.

\section{CONCLUSIONS}

Thus, the inconsistency of the public management system with the modern challenges of time puts them at risk of reducing the efficiency of their activities, increasing the cost of completing the tasks set, reducing the effectiveness of interaction with business and citizens.

The digitalization of society will give equal experience to all citizens in information, services and knowledge, will focus on improving the quality of service delivery in various fields, will significantly improve the efficiency, productivity and competitiveness of the use of digital technologies in all sectors of the economy, will be accompanied by increased confidence and security. The use of new information technologies will promote the development of the information society and the media, as well as enhance links with the European and world environment through the use of common digital standards.

Digital technologies also open up new opportunities for involving citizens in social and political processes through the use of e-democracy tools such as e-parliament, e-voting, e-justice, e-mediation (pre-trial dispute resolution), e-referendum, e-Consultations, e-petitions, e-political campaigns, e-polls and more.

Ukraine has embarked on a general digitization exercise, which entails the need for changes in organizational structures and regulatory support for this process. Real steps have already been taken to overcome the differences between the principles of e-Government and the practical application of the principles stated in the regulations. Since most of the regulations in this field have been strategic in nature and have been implemented by the Association Agreement with the EU, now is the time for conscious action to achieve clearly defined goals and objectives. Implementation of e-government technologies at the proper level and their legal support is not instant and requires both considerable time and considerable effort to adapt the existing Ukrainian legislation. 
The creation of the Ministry of Digital Transformation of Ukraine was a positive achievement in the formulation and implementation of eGovernment policy and coordination of actions in this field by different ministries and agencies. Unlike the previous State Agency for Electronic Governance of Ukraine, the Ministry is empowered with broader authority and is responsible not only for the implementation of the policy but also for its formation.

Ukrainian society still lacks citizens' motivation to translate communication with public authorities into the online environment. This problem is especially true for middle-aged and elderly people who believe that a personal appeal to a public authority is the key to an effective solution. Awareness in the digital field of this category of citizens also plays a negative role in their low interest.

In addition, a large number of civil servants do not see the prospect of mastering new technologies, are not aware of the problems of egovernment and do not see the benefits of implementing it. Moreover, some public servants see the digitalization of public administration as a threat to their professional activities, because they believe it can lead to job cuts and make corruption in the workplace impossible for someone.

These are just some of the problems and challenges facing Ukraine in the context of building a digital society. The speed of response to these challenges will depend on Ukraine's compliance with the requirements of the development of the world economy, quality of life of citizens and compliance with the principles of functioning of a democratic society.

\section{SUMMARY}

The article describes the main directions of development of digital society in Ukraine, in particular the legal basis of the digitalization of the public administration. Analyzes the principles of the state policy of digital development in Ukraine and priority directions of development of electronic management and the use of electronic technologies in public administration, namely: the creation of digital jobs for civil servants, introduction of the concept of open data, use of digital platforms to solve problems in public management, the introduction of a permanent data collection and analysis, the use of technology to the block chain. 
The main tasks of the Central Executive authority on implementation of e-governance. Noted that structural changes in the ministries, in particular the creation of the new Ministry of digital transformation is to facilitate cooperation of different departments and public authorities to respect the principles of transparency and openness of work of public authorities and minimizing corruption in activities of public officials.

An effective modern e-government tool that has become widespread in the public administration system is electronic administrative services, whose delivery process has its advantages and disadvantages.

The introduction of electronic document flow in the work of public authorities is an important step towards the digitalization of the public administration system as a whole. The new government has set itself the goal - by 2020, to fully translate the records in public administration into a digital form, which will help accelerate the workflow and effectively solve problems in public administration.

\section{REFERENCES}

1. Деякі питання оптимізації системи центральних органів виконавчої влади . Постанова Міністрів України від 02 вересня 2019 p. № 829 . URL: https://www.kmu.gov.ua/ua/npas/deyaki-pitannyaoptimizaciyi-sistem-829 (дата звернення 19.09.2019)

2. Деякі питання організації електронної взаємодії державних електронних інформаційних ресурсів . Постанова Кабінету Міністрів України 10.05.2018 № 357. URL: http://zakon.rada.gov.ua/ go/357-2018-\%D0\%BF (дата звернення 09.09.2019)

3. Деякі питання цифрового розвитку. Постанова Кабінету Міністрів від 30 січня 2019 р. № 56 URL: https://zakon.rada.gov.ua/ laws/show/56-2019-\%D0\%BF (дата звернення 10.09.2019)

4. Концепція розвитку цифрової економіки та суспільства України на 2018-2020. Розпорядження Кабінету Міністрів України від 17.01.2018 №67-p. URL: https://zakon.rada.gov.ua/laws/show/672018-\%D1\%80\#n14 (дата звернення 11.09.2019)

5. Лопушинський І.П. «Цифрові робочі місця» державних службовців як вагома складова електронного урядування в Україні. Теорія та практика державного управління $i$ місцевого 
самоврядування. 2018. № 1. URL: http://nbuv.gov.ua/UJRN/Ttpdu_ 2018_1_29 (дата звернення 27.09.2019)

6. Про адміністративні послуги. Закон України від 11.06.2017 № 5203. URL: https://zakon.rada.gov.ua/laws/show/5203-17 (дата звернення 29.09.2019)

7. Про внесення змін до деяких законів України щодо доступу до публічної інформації у формі відкритих даних. Закон України від 25 грудня 2015 р. № 922-VIII. URL: https://zakon.rada.gov.ua/laws/ show/319-19 (дата звернення 27.09.2019)

8. Про внесення змін до постанов Кабінету Міністрів України від 18 липня 2007 р. № 950 і від 17 січня 2018 р. № 55. Постанова Кабінету Міністрів України від 17 квітня 2019 р. № 375. URL: https://zakon.rada.gov.ua/laws/show/375-2019-\%D0\%BF

(дата звернення 27.09.2019)

9. Про доступ до публічної інформації. Закон України від 13 січня 2011 року № 2939-VI. URL: https://zakon.rada.gov.ua/laws/ show/2939-17 (дата звернення 20.09.2019)

10. Про електронні довірчі послуги. Закон України від 5 жовтня 2017 p. № 2155-VIII. Відомості Верховної Ради (ВВР), 2017, № 45, ст. 400 .

11.Про електронні документи та електронний документообіг. Закон України від 22 травня 2003 р. № 851-IV. Відомості Верховної Ради України (ВВР), 2003, № 36, ст. 275.

12.Про затвердження Положення про Державне агентство 3 питань електронного урядування України. Постанова Кабінету Міністрів України від 01.10.2014 № 492. URL: https://zakon.rada.gov.ua /laws/show/492-2014-\%D0\%BF (дата звернення 26.09.2019)

13.Про затвердження Положення про державну реєстрацію нормативно-правових актів міністерств та інших органів виконавчої влади. Постанова Кабінету Міністрів України від 28 грудня 1992 р. № 731. URL: https://zakon.rada.gov.ua/laws/show/731-92-\%D0\%BF (дата звернення 18.09.2019)

14.Про затвердження Положення про набори даних, які підлягають оприлюдненню у формі відкритих даних. Постанова Кабінету Міністрів від 21 жовтня 2015 р. № 835 . URL: 
https://zakon.rada.gov.ua/laws/show/835-2015-\%D0\%BF звернення 19.09.2019)

15.Про затвердження Регламенту Кабінету Міністрів України. Постанова Кабінету Міністрів України від 18 липня 2007p. № 950. URL: https://zakon.rada.gov.ua/laws/show/950-2007-\%D0\%BF (дата звернення 20.09.2019)

16.Про схвалення Концепції розвитку системи електронних послуг в Україні. Розпорядження Кабінету Міністрів України від 16.11.2016 № 918-p. URL: http://zakon.rada.gov.ua/go/918-2016$\%$ D1\%80 (дата звернення 20.09.2019)

17.Рощук М. Розвиток електронного урядування в Україні: правові аспекти забезпечення безпеки інформації // Украйнський науковий журнал безпеки інформащії, 2018, Вип. 24, № 1, С. 17-22.

18.Цифрова адженда України на 2020 рік: проект. URL: https://ucci.org.ua/uploads/files/58e78ee3c3922.pdf (дата звернення 12.09.2019)

Information about the author: Brus T. M., Candidate of Public Administration, Associated Professor, University of Customs and Finance 2/4 Vernadskogo str., Dnipro, 49000, Ukraine 